\title{
Extension of a Chromosome Linkage Group of Proteus mirabilis
}

\author{
By J. N. COETZEE \\ Department of Microbiology, University of Pretoria, Republic of South Africa
}

(Received 9 December 1977; revised 10 February 1978)

\begin{abstract}
Mating procedures for detection of mobilization of the Proteus mirabilis chromosome were re-investigated. The chromosome was mobilized by plasmid $\mathrm{D}$, the previously used hybrid between plasmids P-lac and R1drd19. About a 40-fold increase in recombinant recovery correlated with the absence of swarming during mating and a lower temperature of incubation. The modification introduced was that conjugation was allowed to proceed on a non-selective supplemented minimal medium at $30^{\circ} \mathrm{C}$ before washing and plating on selective media. Final incubation was also at $30^{\circ} \mathrm{C}$. This technique enabled eight additional chromosomal markers to be mapped. Polarized transfer of the chromosome was shown by gradient of transmission experiments using a previously described marker as reference, by linkage analysis with reference to proximal and distal markers and (less successfully) by interrupted mating on solid medium. Markers of plasmid D transferred at high frequency to all recombinants. The plasmid was stable in recombinants and could transfer itself and chromosomal markers of the new hosts in further matings. Resulting recombination of markers occurred at usual frequencies. The marker order, his-1, ser-2, ura-2, pyrB1, trp-3, cysA1, ade-2, ilv-2, cysG1, gly-1, cysC1, argA2, metF2, nalA1, thr-1, leuB2, did not resemble the order of these markers in Escherichia coli.
\end{abstract}

\section{INTRODUCTION}

A plasmid-mediated polarized transfer of eight chromosome markers of $P$. mirabilis has been reported (Coetzee, 1975). The plasmid used was a hybrid of P-lac and R1drd19 (Coetzee, 1974a) and mating took place in broth. Jacob et al. (1976) recorded the failure of R plasmid RP4 bearing inserted fragments of a $P$. mirabilis chromosome to mobilize the $P$. mirabilis chromosome. In this case, mating was attempted in broth as well as on Millipore membranes resting on nutrient agar.

In attempts to demonstrate the transfer of other markers by the first plasmid mentioned, the effect of different mating conditions for the partners concerned was investigated. A measure of success with some procedures was obtained. This paper describes the attempts to define optimal conditions for mating and reports on linkage relationships of additional markers transferred.

\section{METHODS}

Bacteria and plasmids. These are listed in Table 1.

Media. Nutrient broth was Oxoid no. 2 code CM67; nutrient agar was the same broth solidified with $1.2 \%(w / v)$ Difco agar unless otherwise specified. MacConkey agar was from Difco. Minimal medium was that of Grabow \& Smit (1967). For auxotrophic strains this medium was supplemented with amino acids or uracil (each $20 \mu \mathrm{g} \mathrm{ml}^{-1}$ ) when necessary. Incubation temperature was $30^{\circ} \mathrm{C}$, unless otherwise indicated, and media were brought to the corresponding temperature before inoculation.

Antibacterial drugs. The minimal medium contained nalidixic acid $\left(500 \mu \mathrm{g} \mathrm{ml}^{-1}\right)$ or streptomycin $\left(4 \mathrm{mg} \mathrm{ml}^{-1}\right)$ to counterselect donors in some mating experiments. Ampicillin, kanamycin, tetracycline (each $50 \mu \mathrm{g} \mathrm{ml}^{-1}$ ) or rifampicin $\left(200 \mu \mathrm{g} \mathrm{ml}^{-1}\right)$ were added to MacConkey agar when necessary. 


\begin{tabular}{|c|c|}
\hline Bacteria & Relevant properties \\
\hline $\begin{array}{l}\text { Proteus mirabilis } \\
\text { PM5006 }\end{array}$ & Wild type \\
\hline UP3 & $\begin{array}{l}\text { his- } 1 \mathrm{Nal}^{\mathrm{R}} \text { mutant of PM } 5006 \text {. The } \\
\text { locus conferring resistance to more } \\
\text { than } 500 \mu \mathrm{g} \text { nalidixic acid } \mathrm{ml}^{-1} \text { has } \\
\text { been named nalAl }\end{array}$ \\
\hline UP4 & pyrBl mutant of PM5006 nalAI \\
\hline UP7 & tyr-1 mutant of PM5006 str-1 \\
\hline UP12 & ade- 1 mutant of PM5006 nalA1 \\
\hline UP14 & ura-1 mutant of PM5006 str-1 \\
\hline UP16 & $\begin{array}{l}\text { Str }^{R} \text { mutant of UP3. The allele } \\
\text { number of this mutation is str-2 }\end{array}$ \\
\hline UP17 & pyrB2 mutant of UP16 \\
\hline UP41 & cysGI pyrB1 nalA1 । \\
\hline UP42 & gly-1 pyrB1 nalA1 \\
\hline UP43 & cysC1 pyrB1 nalA1 \\
\hline UP44 & $\arg A 2$ pyrB1 nalA1 \\
\hline uP45 & thr-1 pyrBI nalA1 \\
\hline uP46 & metF 2 pyrB1 nalA1 \\
\hline UP47 & leuB2 pyrB1 nalA1 \\
\hline UP48 & tyr-2 pyrBl nalAI \\
\hline UP49 & argEl pyrBl nalAl \\
\hline UP77 & argE2 tyr-1 str-1 \\
\hline UP411 & cysGI nalAI \\
\hline UP422 & gly-1 nalAI \\
\hline UP433 & cysC1 nalA1 \\
\hline UP444 & argA2 nalA1 \\
\hline UP455 & thr-1 nalAI \\
\hline UP466 & metF2 nalA1 \\
\hline UP477 & leuB2 nalA1 \\
\hline UP488 & tyr-2 nalAl \\
\hline UP499 & argEl nalAl \\
\hline
\end{tabular}

Escherichia coli s53-2

\section{Plasmids and hosts}

\section{Proteus mirabilis PM5006(D)}

PM5006(RP4-PM1) PM5006(RP4-PM2) PM5006(RP4-PM3) UP24(D)

UP41(D), UP42(D), UP43(D), UP44(D), UP45(D), UP46(D), UP47(D), UP48(D), UP49(D), UP77(D)

Escherichia coli J62-1(D)

Rifampicin resistant mutant of $\mathrm{J} 53$, an $\mathrm{F}^{-}$pro met mutant of $E$. coli $\mathrm{x} 12$

$\mathrm{D}$ is the new symbol for plasmid

P-lac $\overline{\mathrm{R} 1 d r d 1}$ 9*. Molecular

weight about $120 \times 10^{6}$

PM5006 carrying R plasmid RP4 into

which different segments of $P$.

mirabilis DNA had been inserted

ilv-2 mutant of UP16 carrying plasmid D

Derivatives of listed strains

carrying plasmid $\mathbf{D}$

\section{Table 1. Bacteria and plasmids}

Reference(s)

Coetzee et al. (1968); Coetzee \& Smit (1970); Niemand (1971); Krizsanovich (1973); Coetzee (1974b)

Coetzee (1975)

Coetzee (1975)

Coetzee (1975)

Coetzee (1975)

Coetzee (1975)

Coetzee (1975)

Coetzee (1975)

$N$-Methyl- $N^{\prime}$-nitro- $N$-nitrosoguanidine (NTG) induced mutants of UP4 (unpublished)

NTG induced mutant of UP7

(Coetzee, 1975, and unpublished)

Spontaneous revertant of UP41

Spontaneous revertant of UP42

Spontaneous revertant of UP43

Spontaneous revertant of UP44

Spontaneous revertant of UP45

Spontaneous revertant of UP46

Spontaneous revertant of UP47

Spontaneous revertant of UP48

Spontaneous revertant of UP49

Clowes \& Hayes (1968);

R. W. Hedges

Coetzee (1974a, 1975 and this paper); W. F. Coetzee (personal communication)

Jacob et al. (1976)

Coetzee $(1974 a, 1975)$

This paper

Coetzee (1975); Clowes \& Hayes (1968) an $\mathrm{F}^{-}$lac pro his trp strain of E. coli $\mathrm{K} 12$ carrying plasmid $\mathrm{P}-\mathrm{lac} \widehat{\mathrm{R} 1 d r d 19}$ $\mathrm{J} 62$, as resident

* Superior line indicates transduced $\mathbf{R}$ plasmid. 


\section{Table 2. Matings on different solid media}

The donor was UP77(D) and recipients were UP3, UP4 and UP12. Mating mixtures were constituted as described for solid media matings in Methods. After incubation for $3 \mathrm{~h}$ at the stated temperature, the growth was harvested, washed and dilutions were plated on minimal medium containing nalidixic acid. Plates were then incubated for $48 \mathrm{~h}$ at the temperature used for mating.

\begin{tabular}{|c|c|c|c|c|}
\hline \multirow[b]{2}{*}{ Medium } & \multirow{2}{*}{$\begin{array}{c}\text { Mating } \\
\text { temp. } \\
\left({ }^{\circ} \mathrm{C}\right)\end{array}$} & \multicolumn{3}{|c|}{ Recovery of recombinants per donor cell } \\
\hline & & $h i s-I^{+}$ & pvrB1+ & ade $-I^{+}$ \\
\hline Nutrient agar & $\begin{array}{l}43 \\
37 \\
30\end{array}$ & $\begin{array}{l}3 \times 10^{-5} \\
2 \times 10^{-6} \\
4 \times 10^{-6}\end{array}$ & $\begin{array}{l}7 \times 10^{-6} \\
7 \times 10^{-7} \\
9 \times 10^{-7}\end{array}$ & $\begin{array}{l}2 \times 10^{-6} \\
2 \times 10^{-7} \\
3 \times 10^{-7}\end{array}$ \\
\hline $6 \%$ Nutrient agar* & $\begin{array}{l}43 \\
37 \\
30\end{array}$ & $\begin{array}{l}2 \times 10^{-5} \\
2 \times 10^{-5} \\
4 \times 10^{-5}\end{array}$ & $\begin{array}{l}5 \times 10^{-6} \\
5 \times 10^{-6} \\
8 \times 10^{-6}\end{array}$ & $\begin{array}{l}1 \times 10^{-6} \\
1 \times 10^{-6} \\
2 \times 10^{-6}\end{array}$ \\
\hline Non-selective minimal medium $\dagger$ & $\begin{array}{l}43 \\
37 \\
30\end{array}$ & $\begin{array}{l}4 \times 10^{-5} \\
4 \times 10^{-5} \\
2 \times 10^{-4}\end{array}$ & $\begin{array}{l}1 \times 10^{-5} \\
2 \times 10^{-5} \\
4 \times 10^{-5}\end{array}$ & $\begin{array}{l}2 \times 10^{-6} \\
2 \times 10^{-6} \\
4 \times 10^{-6}\end{array}$ \\
\hline $\begin{array}{l}\text { Total recipient selective } \\
\text { medium }\end{array}$ & $\begin{array}{l}43 \\
37 \\
30\end{array}$ & $\begin{array}{l}8 \times 10^{-7} \\
8 \times 10^{-7} \\
1 \times 10^{-6}\end{array}$ & $\begin{array}{l}4 \times 10^{-7} \\
4 \times 10^{-7} \\
6 \times 10^{-7}\end{array}$ & $\begin{array}{l}1 \times 10^{-7} \\
9 \times 10^{-8} \\
2 \times 10^{-7}\end{array}$ \\
\hline $\begin{array}{l}\text { Millipore membrane on non- } \\
\text { selective minimal medium }\end{array}$ & $\begin{array}{l}43 \\
37 \\
30\end{array}$ & $\begin{array}{l}6 \times 10^{-7} \\
6 \times 10^{-7} \\
8 \times 10^{-7}\end{array}$ & $\begin{array}{l}3 \times 10^{-7} \\
3 \times 10^{-7} \\
3 \times 10^{-7}\end{array}$ & $\begin{array}{l}6 \times 10^{-8} \\
4 \times 10^{-8} \\
6 \times 10^{-8}\end{array}$ \\
\hline
\end{tabular}

* Nutrient broth solidified with $6 \%(\mathrm{w} / \mathrm{v})$ Difco agar.

$\dagger$ Minimal medium supplemented with the growth requirements of both donor and recipient with omission of a donor counterselective agent, nalidixic acid.

$\ddagger$ Minimal medium supplemented with the growth requirement of the recipient without nalidixic acid.

Construction of $P$. mirabilis UP strains containing plasmid $D$. This was accomplished by the method of Coetzee et al. (1973), using tetracycline to counterselect the Escherichia coli strain. All donor strains were maintained on nutrient agar slopes containing kanamycin at $10^{\circ} \mathrm{C}$. They were subcultured at intervals of about 2 months.

Bacterial conjugation on solid media. The donor culture was prepared by diluting an overnight broth culture 1:10 in prewarmed broth and incubating for $90 \mathrm{~min}$. Overnight broth cultures of recipients were used. The partners were mixed by spreading $0 \cdot 1 \mathrm{ml}$ of donor and $0 \cdot 1 \mathrm{ml}$ of recipient on an agar surface. When Millipore membranes were used, the same volumes were rapidly filtered and the membrane with impinged bacteria was placed on an appropriate solid medium. After $3 \mathrm{~h}$ incubation at $30^{\circ} \mathrm{C}$ (unless otherwise stated), the growth was harvested in sterile saline and centrifuged; the deposit was once again washed in saline and resuspended and then dilutions were plated on selective media for recombinants and transconjugants. Control experiments lacked either donor or recipient. Plates were incubated for $48 \mathrm{~h}$ before results were scored.

Interrupted mating. This was done according to the solid medium technique of Haas \& Holloway (1976). Briefly, $0.1 \mathrm{ml}$ of recipient was spread on plates containing $10 \mathrm{ml}$ minimal agar medium (appropriately supplemented when necessary) prior to the addition at zero time of $0 \cdot 1 \mathrm{ml}$ of the donor culture prepared as above. Mating was interrupted by spreading $1.25 \mathrm{ml}$ of a freshly prepared nalidixic acid solution $(4.0 \mathrm{mg}$ $\mathrm{ml}^{-1}$ ) carefully over the surface of the agar to mix the bacterial growth thoroughly. Plates were dried for $1 \mathrm{~h}$ with lids partly open and then incubated.

Unselected marker analysis. Recombinant clones were purified on agar similar to that used for selection. Single colonies were then suspended in $0.5 \mathrm{ml}$ saline and loopfuls were spotted on selective and control media.

\section{RESULTS \\ Optimal mating conditions}

Mating on different solid media. To cover a range of markers, separate experiments were done with UP3 (his-1), UP4 (pyrBl) and UP12 (ade-1) as recipients and UP77(D) [argE2 tyr-1 str-1 (D)] as donor. In fluid matings (Coetzee, 1975), recombinants for the his, pyrB and ade markers involved were recovered at about $5 \times 10^{-6}, 1 \times 10^{-6}$ and $2 \times 10^{-6}$ per donor cell 
Table 3. Gradient of transmission of markers in relation to an internal standard of pyr $B^{+}$recombinants in same cross

Mating mixtures were constituted as described in Methods on non-selective minimal medium with PM5006(D) as donor. After $3 \mathrm{~h}$ incubation at $30^{\circ} \mathrm{C}$, the growth was harvested, washed and dilutions were plated on two types of minimal medium containing nalidixic acid: for detection of specific markers media were supplemented with uracil; for $p y r B^{+}$recombinants the medium contained the growth requirement of the specific marker involved in the cross.

\begin{tabular}{|c|c|c|}
\hline Recipient & $\begin{array}{l}\text { Specific donor } \\
\text { marker }\end{array}$ & $\begin{array}{c}\text { Recombinants per } \\
10^{4} \text { pyr } B^{+*}\end{array}$ \\
\hline UP41 & cysG $1^{+}$ & 711 \\
\hline UP42 & $g l y-1^{+}$ & 522 \\
\hline UP43 & cys $C 1^{+}$ & 434 \\
\hline UP44 & $\arg A 2^{+}$ & 376 \\
\hline UP45 & $t h r-1^{+}$ & 22 \\
\hline UP46 & metF2+ & 15 \\
\hline UP47 & $\operatorname{leuB2^{+}}$ & 10 \\
\hline UP48 & tyr-2+ & 0 \\
\hline UP49 & $\arg E 1^{+}$ & 0 \\
\hline
\end{tabular}

respectively. These recoveries were confirmed in similar experiments done in nutrient broth (not shown). It is seen from Table 2 that (i) conjugations on non-selective minimal agar medium at $30{ }^{\circ} \mathrm{C}$ resulted in about a 40 -fold increase in recombinant recovery; (ii) matings on nutrient agar at $43{ }^{\circ} \mathrm{C}$ resulted in recombinant recoveries similar to those on $6 \%$ nutrient agar at all temperatures, while those executed on Millipore membranes gave consistently lower recoveries; (iii) matings on media selective for total recipients (see Dennison \& Baumberg, 1975b) yielded fewer recombinants; and (iv) mating at lower temperatures tended to give higher recoveries of recombinants. The combination of non-selective minimal medium and $30^{\circ} \mathrm{C}$ appeared optimal, although all combinations of recombinant selection media and temperature had not been tested.

\section{Chromosome mapping}

In view of the above findings it was decided to test a range of new markers under optimal conditions for mobilization by plasmid D and the plasmids constructed by Jacob et al. (1976).

Gradient of transmission. Strains bearing various additional single auxotrophic mutations to the pyrB1 mutation in parent strain UP4 were used as recipients in recombination experiments with PM5006(D), PM5006(RP4-PM1), PM5006(RP4-PM2) and PM5006(RP4-PM3) as possible chromosome donors. PyrBI (Fig. 1) is a marker situated in the middle of the chromosome linkage group previously reported by Coetzee (1975).

Chromosomal markers not studied before (Coetzee, 1975) were mobilized by plasmid D (Fig. 1) and a gradient of transmission existed with respect to $p y r B^{+}$recombinants used as internal standard (Table 3). Also alleles of markers arg-1, leu-1 and met-1 [subsequently identified as being $\arg A 1$, leuBl and metF1 (unpublished results)], which had failed to produce recombinants previously (Coetzee, 1975), now registered in experiments (Fig. 1). No recombinants were encountered with potential donors bearing the RP4 variant plasmids and work with them was abandoned.

Linkage analysis. On the basis of the recovery of recombinants listed in Table 3, the markers were divided in two groups; UP48 (tyr-2) and UP49 (argE1), markers which had failed to yield recombinants (Table 3), were incorporated in both groups. Markers of the first group were tested for linkage to $i l v-2$ the most distal marker previously recorded (Coetzee, 1975). Selection was for recombinants of the (presumed) distal markers of the first group, and then the proportion which had also incorporated the proximal ilv- 2 marker was determined. The markers could thus be arranged in the sequence $i l v-2, c y s G 1, g l y-1$, 


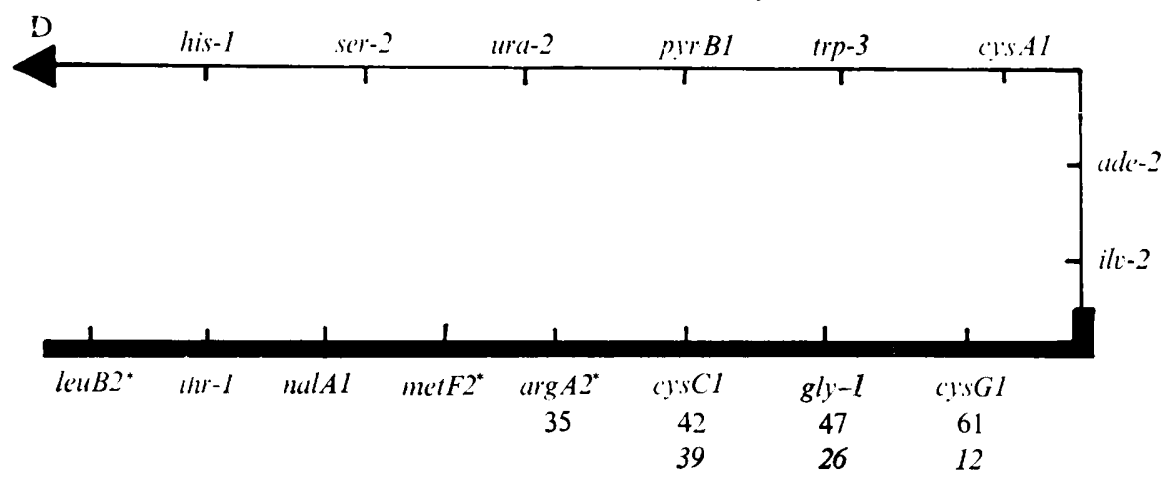

Fig. 1. Chromosomal linkage group of Proteus mirabilis PM5006. Thin and thick lines indicate the linkage group reported previously (Coetzee, 1975) and the present extension, respectively. Markers are arbitrarily spaced. nalAl maps closely to $t h r-1$ and metF2 in two-factor crosses (see Table 5) but its exact location is undetermined. Numbers below alleles represent percentages of particular prototrophic recombinants which had also incorporated the proximal $i l v-2^{+}$donor marker. Italicized numbers likewise represent percentages of particular recombinants which had also incorporated the distal $\arg A 2^{+}$donor marker. Asterisks indicate alleles of markers arg-1, leu-1, met-I from which recombinants had not previously (Coetzee, 1975) been recovered.

Table 4. Linkage of distal markers to cysCl expressed as the number of prototrophic recombinants of markers which had also incorporated the proximal cysC1 donor marker

Matings were done as described in Methods and in the legend to Table 3. The donor was UP43(D). Selection was on minimal medium supplemented with cysteine. Recombinants were tested for presence of the unselected donor marker cys $C 1$.

$\begin{array}{ccc}\text { Recipient } & \begin{array}{c}\text { Selected recipient } \\ \text { marker }\end{array} & \begin{array}{c}\text { Double recombinants* } \\ (\%)\end{array} \\ \text { UP444 } & \text { argA2 } & 59 \\ \text { UP455 } & \text { thr-1 } & 20 \\ \text { UP466 } & \text { metF2 } & 35 \\ \text { UP477 } & \text { leuB2 } & 12 \\ \text { UP488 } & \text { tyr-2 } & 0 \\ \text { UP499 } & \text { argEl } & 0\end{array}$

* About 200 recombinants, from two experiments, were examined.

cysC1, $\arg A 2$ (Fig. 1). No recombinants were obtained with markers $t y r-2$ and $\arg E 1$. The more conventional method (Hayes et al., 1963) of testing for recombinants of a proximal marker and then determining the proportion which had also incorporated distal markers, yielded an identical order (Fig. 1).

Possible linkage of markers in the second group to those of the first was determined by estimating the proportion of recombinants for (presumed) distal markers which had also incorporated the proximal cysCl marker of the first group (Table 4). With one exception, a reversal of the order for markers $t h r-1$ and $m e t F 2$, the sequence tallied with that based on the recovery of recombinants listed in Table 3. Again no recombinants were obtained with markers $t y r-2$ and $\arg E 1$.

It has been suggested (Coetzee, 1975) that a locus controlling nalidixic acid resistance (nalAl) is distantly linked to $i l v-2$. This was tested by crossing various nalidixic acid resistant donor strains bearing another marker with the wild type. Selection was for $\mathrm{Nal}^{\mathrm{R}}$ and recovery of double recombinants with the other donor marker was determined. Loci nalAl, $t h r-1$ and $m e t F 2$ were found to be closely linked (Table 5, lines 5, 6). Reverse crosses (Table 5, lines 10,11$)$ confirmed the linkage and provisionally set the locus proximal to thr- 1 although three-factor crosses were not done. This location of nalAl could explain the very low frequencies of recombinants encountered for the $t h r-1, m e t F 2$ and leuB2 loci (Table 3) where 


\section{Table 5. Linkage of markers to nalA locus}

Matings were done as described in Methods and in the legend to Table 3. In crosses with up41(D) to UP49(D) as donors, the recombinant minimal selective media contained nalidixic acid and the amino acid corresponding to the unselected marker of the donor. In crosses with UP77(D) as donor, recombinant selection was on unsupplemented minimal media. Recombinants were tested for the presence of the unselected marker.

$\begin{array}{ccccc}\text { Donor } & \text { Recipient } & \begin{array}{c}\text { Selected } \\ \text { recipient } \\ \text { marker }\end{array} & \begin{array}{c}\text { Unselected } \\ \text { donor marker }\end{array} & \begin{array}{c}\text { Double } \\ \text { recombinants* } \\ (\%)\end{array} \\ \text { UP41(D) } & \text { PM5006 } & \text { nalA1 } & \text { cysG1 } & 14 \\ \text { UP42(D) } & \text { PM5006 } & \text { nalA1 } & \text { gly-1 } & 22 \\ \text { UP43(D) } & \text { PM5006 } & \text { nalA1 } & \text { cysC1 } & 26 \\ \text { UP44(D) } & \text { PM5006 } & \text { nalA1 } & \text { argA2 } & 30 \\ \text { UP45(D) } & \text { PM5006 } & \text { nalAl } & \text { thr-1 } & 47 \\ \text { UP46(D) } & \text { PM5006 } & \text { nalA1 } & \text { metF2 } & 81 \\ \text { UP47(D) } & \text { PM5006 } & \text { nalA1 } & \text { leuB2 } & 6 \\ \text { UP48(D) } & \text { PM5006 } & \text { nalA1 } & \text { tyr-2 } & 0 \\ \text { UP49(D) } & \text { PM5006 } & \text { nalA1 } & \text { argE1 } & 0 \\ \text { UP77(D) } & \text { UP455 } & \text { thr-1 } & \text { Nal } & 89 \\ \text { UP77(D) } & \text { UP466 } & \text { metF2 } & \text { Nal } & 56\end{array}$

* About 90 recombinants, from three experiments, were examined.

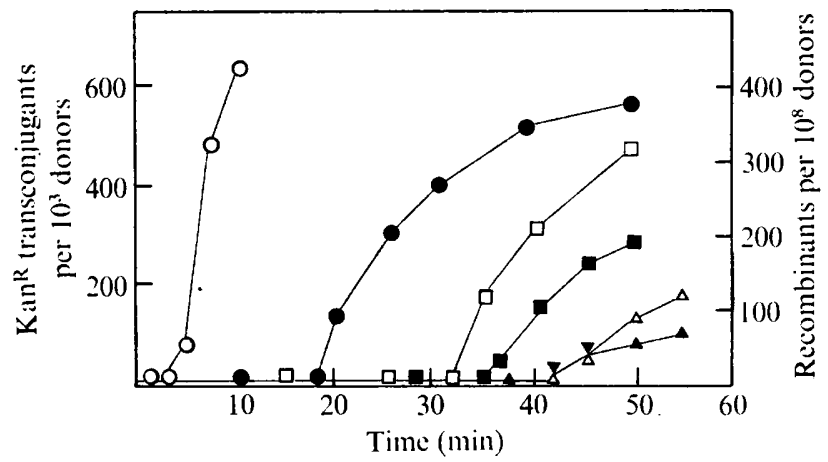

Fig. 2. Time of entry of donor markers. The donor was the double auxotrophic nalidixic acid sensitive strain UP77(D). Mating mixtures were constituted as detailed in Methods, and mating was interrupted at intervals by spreading plates with a nalidixic acid solution. Plates were then dried and incubated for $48 \mathrm{~h}$. Results are those of duplicate experiments. For plasmid transfer, the recipient strain was UP41 and the minimal media contained kanamycin, cysteine and uracil. For crosses involving transfer of chromosomal markers with recipients UP41, UP42, UP43 and UP44, unsupplemented Iminimal medium was used. $\bigcirc$, Plasmid D;, pyrBI (per $10^{7}$ donor cells); $\square$, cys $G I ; \mathbf{m}$, gly-1; $\triangle$, cysC1; $\Delta, \operatorname{argA2}$.

nalidixic acid was used to select recombinants. It could also explain the discrepancy encountered with the $t h r-1$ and metF2 loci (see Table 3, lines 5, 6, and Table 4, lines 2, 3).

Interrupted mating. These experiments with crosses involving a double auxotrophic donor and various auxotrophic nalidixic acid resistant recipients yielded a reproducible temporal order of entry of markers $c y s G 1, g l y-1$, and $c y s C l$ and $\operatorname{argA2}$ (Fig. 2). The times of entry of $\operatorname{cys} C 1$ and $\operatorname{argA2}$ could not be separated and both registered at about $42 \mathrm{~min}$. For cys $G 1$ and $g l y-1$, at least, results of linkage analyses were confirmed (Fig. 1). Confidence in these experiments was increased by two other observations. Firstly, plates where mating was interrupted at time zero showed none or very few recombinants (see Haas \& Holloway, 1976). This proved that no significant second-round mating occurred once it had been interrupted. Secondly, the time of entry of pyrBl agreed closely with that determined by mating in broth (Coetzee, 1975). Markers more distally situated (Table 4) gave too few recombinants, by this method of mating, to yield reproducible results. As previously recorded, plasmid transfer was early and occurred at high frequency (Coetzee, 1975). 


\section{Properties of plasmid $D$}

Inheritance. All of about 1400 recombinants from various crosses had received the lactose fermentation marker (not shown) as well as the antibiotic resistance properties associated with plasmid D. These results are in accord with those published previously (Coetzee, 1975). Also, recombinants transferred the plasmid at high frequency to $E$. coli strain J63-2 with counterselection of donors with rifampicin (not shown). Eight recombinants, chosen at random, were mated on non-selective minimal medium with strain UP14 in the usual way but with streptomycin as donor counterselective agent. The frequency of recombinant formation for the ura-1 marker was constant at about $5 \times 10^{-5}$ per donor cell (not shown). A similar recovery was obtained in recombination tests employing the same recipient and the standard wild-type donor PM5006(D). All recombinants had received the D plasmid. These results are representative of a number of similar experiments.

Stability. Under the conditions of maintenance and selection employed (see Methods), donor ability was a stable feature and reproducible results were obtained with the same donor strain in experiments separated by intervals of about 2 years (not shown).

\section{DISCUSSION}

Falkow et al. (1964) demonstrated that the frequency of conjugal transfer of E. coli lac genes by $P$. mirabilis was at least 50 -fold higher on agar surface matings than in liquid medium. Subsequently many workers (see Mojica-a \& Middleton, 1971; Pühler et al., 1972; Moody \& Runge, 1972; Wohlhieter et al., 1975; Dennison \& Baumberg, 1975 a; Jollick \& Tran, 1975; Cannon \& Postgate, 1976; Haas \& Holloway, 1976; Towner \& Vivian, 1977; Kondorosi et al., 1977; Morgan \& Kaplan, 1977) employed this form of mating in attempts to satisfy the mating idiosyncrasies of a wide variety of organisms. It must be noted that the difference mentioned above between surface and liquid matings does not necessarily apply to plasmid transfer between Proteus strains (Dennison \& Baumberg, 1975a; Jacob et al., 1976). The fact that markers dispersed over the existing linkage group gave increased recombinant recovery with the new (and not the old) method of mating while maintaining a gradient of transmission (Table 2), argued against a spontaneous mutant of $\mathrm{D}$ being involved in transfer.

Proteus hauseri strains do not swarm at $43{ }^{\circ} \mathrm{C}$ on any medium (Coetzee \& De Klerk, 1964) or on $6 \%$ nutrient agar (Hayward \& Miles, 1943) or minimal medium at any temperature (unpublished observations). Apart from the membrane technique, the frequency of chromosomal recombination for $P$. mirabilis correlated well with absence of swarming and this failure to swarm on the minimal medium may be the cause of the increased recovery of recombinants encountered. No explanation can be given for the failure of the Millipore membrane technique. Towner \& Vivian $(1976 a, b)$ found it indispensable for the demonstration of chromosomal transfer in a strain of Acinetobacter and the membrane technique has become standard practice in transduction experiments with phage $5006 \mathrm{M}$ (see Coetzee, $1974 b)$. The strict temperature requirement $\left(37^{\circ} \mathrm{C}\right)$ for R1-mediated $E$. coli intraspecies chromosomal transfer (Pearce \& Meynell, 1968) was not encountered, and transfer occurred over a range of more than $10{ }^{\circ} \mathrm{C}$ in the $P$. mirabilis crosses with an optimum at $30{ }^{\circ} \mathrm{C}$. This could be due to the different hosts involved or because transfer was under control of the P-lac element of the fused plasmid (see Coetzee, 1974a, 1975).

The acquisition of chromosome donor ability in Pseudomonas aeruginosa by plasmid R68 was accompanied by an increase in molecular weight corresponding to that of an insertion sequence (Starlinger \& Saedler, 1972; Jacob et al., 1977). This insertion could be accompanied by deletions of genes close by (Reif \& Saedler, 1975; and see Jacob et al., 1977). Jacob et al. $(1976,1977)$ suggested that chromosome mobilization by R68.45 was due to interaction between insertion sequences on the plasmid and on the Ps. aeruginosa chromo- 
some. It is not known how plasmid D mobilizes the $P$. mirabilis chromosome but the behaviour of the latter plasmid differed in a number of respects from that of R68.45 (see Haas \& Holloway, 1976). Thus, donor ability of plasmid D was a stable property which differed from that of R68.45-carrying strains where continuous supervision and selection was required; plasmid D in apparently unchanged form (see above) was present and stable in all recombinants, but $\mathrm{R} 68.45$ became unstable after involvement in chromosomal transfer with partial or complete loss of plasmid markers in a substantial proportion of Ps. aeruginosa progeny (Haas \& Holloway, 1976). Also R68.45 promoted chromosome transfer from a number of sites on the Ps. aeruginosa chromosome whereas all chromosome markers mobilized by $\mathrm{D}$ fell within one linkage group. These considerations made it unlikely that interaction of insertion sequences, in the manner envisaged for R68.45, could explain chromosomal transfer by plasmid D in $P$. mirabilis. However, the plasmids involved differ greatly (amongst other properties) in molecular weight and it could be that interactions which occurred in 'silent' areas of plasmid D would only be detected with physical studies. Possible reasons why RP4-PM1, RP4-PM2 and RP4-PM3 failed to mobilize the $P$. mirabilis chromosome have been discussed at length by Jacob et al. (1976).

As the limit of the D-guided chromosome trajectory is reached, distinction between markers becomes less clear. Although loci $c y s C 1$ and $\arg A 2$ and $m e t F 2$, thr-1, leuB2 could be clearly distinguished by means of linkage analysis, the resolution of kinetic experiments was inadequate to distinguish times of entry of the first two markers, while recovery of specific recombinants for the other three markers was not reproducible.

The $c y s-1$ marker of strain UP13 (Coetzee, 1975) has been identified as $c y s A l$ (unpublished) and the $P$. mirabilis linkage group, corresponding to a transfer time interval of more than $40 \mathrm{~min}$, comprises the following: his-1, ser-2, ura-2, pyrB1, trp-3, cysA1, ade-2, ilv-2, cysG1, gly-1, cysC1, $\arg A 2$, metF2, nalA1, thr-1, leuB2. As far as gene arrangement is concerned, there appears to be no similarity between $E$. coli and $P$. mirabilis. In view of the considerable time-length of chromosome already transferred, it appears inevitable that the statement about the map order of $P$. mirabilis differing markedly from that of $E$. coli (see Sanderson, 1976) will stand. Marked differences are in accord with the fact that Brenner et al. (1969) only detected $6 \%$ relatedness between $E$. coli DNA and that of $P$. mirabilis. Also, following the conjugal introduction of large segments of $E$. coli DNA into P. mirabilis (Wohlhieter et al., 1975), there was no evidence of integration of these genes into the P. mirabilis chromosome (but see Morgan \& Kaplan, 1977).

The chromosome map of $P$. mirabilis has been extended, but the quest to obtain genetic evidence for circularity of the chromosome seems destined to follow the same tedious course as that of Ps. aeruginosa (see Holloway, 1975). This evidence may only be forthcoming with the discovery of either a variant of the present sex factor or another plasmid capable of promoting chromosomal transfer from other sites. Preliminary evidence (unpublished) indicates that a P-1 incompatibility group plasmid, R772, can mobilize the $P$. mirabilis chromosome. The ability of this plasmid to do so from different chromosomal sites is being investigated.

The author is in receipt of grants from the South African Medical Research Council.

\section{REFERENCES}

Brenner, D. J., FAnning, G. R., Johnson, K. E., Citarella, R. V. \& Falkow, S. (1969). Polynucleotide sequence relationships among members of Enterobacteriaceae. Journal of Bacteriology 98, 637-650.

Cannon, F. C. \& Postgate, J. R. (1976). Expression of Klebsiella nitrogen fixation genes (nif) in Azotobacter. Nature, London 260, 271-272.
Clowes, R. C. \& Hayes, W. (1968). Experiments in Microbial Genetics. Oxford and Edinburgh: Blackwell Scientific Publications.

Coetzee, H. L., De Klerk, H. C., Coetzee, J. N. \& SMIT, J. A. (1968). Bacteriophage-tail-like particles associated with intra-species killing of Proteus vulgaris. Journal of General Virology 2, 29-36. 
Coetzee, J. N. (1974a). Properties of Proteus and Providence strains harbouring recombinant plasmids between P-lac R1drd19 or R447b. Journal of General Microbiology 80, 119-130.

Coetzee, J. N. (1974b). High frequency transduction of kanamycin resistance in Proteus mirabilis. Journal of General Microbiology 84, 285-296.

Coetzee, J. N. (1975). Chromosome transfer in Proteus mirabilis mediated by a hybrid plasmid. Journal of General Microbiology 86, 133-146.

Coetzee, J. N. \& De KLeRK, H. C. (1964). Effect of temperature on flagellation, motility and swarming of Proteus. Nature, London 202, 211-212.

Coetzee, J. N. \& Smit, J. A. (1970). Properties of Proteus mirabilis phage 13vir. Journal of General Virology 9, 247-249.

Coetzee, J. N., Datta, N., Hedges, R. W. \& Appelbaum, P. C. (1973). Transduction of $\mathbf{R}$ factors in Proteus mirabilis and $P$. rettgeri. Journal of General Microbiology 76, 355-368.

Dennison, S. \& BaumberG, S. (1975a). Unusual characteristics of the receptor for the $N$ sex factor-specific filamentous phage IKe. Genetical Research 25, 275-284.

Dennison, S. \& Baumberg, S. (1975b). Conjugational behaviour of $\mathrm{N}$ plasmids in Escherichia coli K12. Molecular and General Genetics 138, 323-331.

Falkow, S., Wohlhieter, J. A., Citarella, R. V. \& BARON, L. S. (1964). Transfer of episomic elements to Proteus. I. Transfer of F-linked chromosomal determinants. Journal of Bacteriology 87, 209-219.

Grabow, W. O. K. \& Smit, J. A. (1967). Methionine synthesis in Proteus mirabilis. Journal of General Microbiology 46, 47-57.

HaAs, D. \& Holloway, B. W. (1976). R factor variants with enhanced sex factor activity in Pseudomonas aeruginosa. Molecular and General Genetics 144, 243-251.

Hayes, W., Jacob, F. \& Wollman, E. L. (1963). Conjugation in bacteria. In Methodology in Basic Genetics, pp. 129-164. Edited by W. J. Burdette. San Francisco: Holden-Day.

Hayward, N. J. \& Miles, A. A. (1943). Inhibition of Proteus in cultures from wounds. Lancet ii, 116-117.

Holloway, B. W. (1975). Genetic organization of Pseudomonas. In Genetics and Biochemistry of Pseudomonas, pp. 133-161. Edited by P.H. Clarke and M. H. Richmond. London: Wiley.

Jacob, A. E., Cresswell, J. M., Hedges, R. W., Coetzee, J. N. \& Beringer, J. E. (1976). Properties of plasmids constructed by the in vitro insertion of DNA from Rhizobium leguminosarum or Proteus mirabilis into RP4. Molecular and General Genetics 147, 315-323.

Jacob, A. E., Cresswell, J. M. \& Hedges, R. W. (1977). Molecular characterization of the $P$ group plasmid R68 and variants with enhanced chromosome mobilizing ability. FEMS Microbiology Letters 1, 71-74.

Jollick, J. D. \& Tran, T. Q. (1975). Polarity of gene transfer in Caulobacter. Journal of General Microbiology 91, 183-187.

Kondorosi, A., Kiss, G. B., Forrai, T., Vincze, E. \& Banfalvi, Z. (1977). Circular linkage map of Rhizobium meliloti chromosome. Nature, London 268, 525-527.

Krizsanovich, K. (1973). Cryptic lysogeny in Proteus mirabilis. Journal of General Virology 19, 311-320.

MojicA-A, T. \& Middleton, R. B. (1971). Fertility of Salmonella typhimurium crosses with Escherichia coli. Journal of Bacteriology 108, 1161-1167.

Moody, E. E. M. \& Runge, R. (1972). The integration of autonomous transmissible plasmids into the chromosome of Escherichia coli $\mathrm{K} 12$. Genetical Research 19, 181-186.

Morgan, E. A. \& Kaplan, S. (1977). Expression and stability of Escherichia coli F-prime factors in Proteus mirabilis. Molecular and General Genetics 151, 41-47.

Niemand, J. G. (1971). A classification of bacteriocins active on a strain of Proteus mirabilis. M.Sc. thesis, University of Pretoria, South Africa.

Pearce, L. E. \& Meynell, E. (1968). Specific chromosomal affinity of a resistance factor. Journal of General Microbiology 50, 159-172.

Pühler, A., Burkardt, H. J. \& HeumanN, W. (1972). Genetic experiments with the Pseudomonas aeruginosa R-factor RP4 in Rhizobium lupini. Journal of General Microbiology 73, xxvi.

REIF, H. J. \& SAEDLER, H. (1975). Is1 is involved in deletion formation in the gal region of $E$. coli K12. Molecular and General Genetics 137, 17-28.

SANDERson, K. E. (1976). Genetic relatedness in the family Enterobacteriaceae. Annual Review of Microbiology 30, 327-349.

Starlinger, P. \& SaEdler, H. (1972). Insertion mutations in micro-organisms. Biochimie 54, 177-185.

TOWNER, K. J. \& ViviAN, A. (1976a). RP4-mediated conjugation in Acinetobacter calcoaceticus. Journal of General Microbiology 93, 355-360.

TOWNER, K. J. \& VIVIAN, A. (1976b). RP4 fertility variants in Acinetobacter calcoaceticus. Genetical Research 28, 301-306.

Towner, K. J. \& Vivian, A. (1977). Plasmids capable of transfer and chromosome mobilization in Acinetobacter calcoaceticus. Journal of General Microbiology 102, 167-171.

Wohlhieter, J. A., Gemski, P. \& Baron, L. S. (1975). Extensive segments of Escherichia coli $\mathrm{K} 12$ chromosome in Proteus mirabilis diploids. Molecular and General Genetics 139, 92-102. 